УДК 026:37:[014.3:004.65](477)

Демида Євгенія Федорівна

науковий співробітник відділу наукової інформаційно-бібліографічної діяльності

Державна науково-педагогічна бібліотека України імені В. О. Сухомлинського, м. Київ, Україна

EvgeshaDem@i.ua

\title{
ФОРМУВАННЯ БАЗИ ДАНИХ «ПЕРІОДИКА» ЕЛЕКТРОННОГО КАТАЛОГУ ДЕРЖАВНОЇ НАУКОВО-ПЕДАГОГІЧНОЇ БІБЛІОТЕКИ УКРАЇНИ ІМЕНІ В. О. СУХОМЛИНСЬКОГО: ЗДОБУТКИ І МОЖЛИВОСТІ МОДЕРНІЗАЦІЇ
}

\begin{abstract}
Анотація. У статті представлено інформаційний бібліографічний ресурс - базу даних «Періодика» електронного каталогу Державної науково-педагогічної бібліотеки України імені В.О. Сухомлинського, що розкриває зміст фонду сучасних періодичних видань книгозбірні. Висвітлено організаційні аспекти формування цього ресурсу й окреслено низку завдань щодо його модернізації, рішення яких можуть забезпечити можливості технологічної платформи бази даних - система автоматизації бібліотек (САБ) ІРБІС 64. Виконання завдань дасть змогу значно покращити якість й ефективність автоматизованого аналітико-синтетичного опрацювання періодичних видань i рівень бібліографічного обслуговування користувачів.
\end{abstract}

Ключові слова: Державна науково-педагогічна бібліотека України імені В. О. Сухомлинського; періодичні видання; бібліографічна база даних; електронний каталог; САБ ІРБІС 64; модернізація.

\section{1. ВСТУП}

Постановка проблеми. Прогрес держави залежить від якості і рівня освіченості громадян, відповідності останнього сучасним потребам суспільства. Як зазначив президент НАПН України В.Г. Кремень, «для підготовки людини до життя в сучасному світі потрібна система освіти, яка орієнтує на усвідомлення сутності змін, привнесених новим часом, на їх послідовне й динамічне сприйняття. Безумовно, інноваційна освіта має готувати людину до життя і діяльності в нових умовах» $[1,5]$. Пошуком нових підходів, парадигм переймаються науковці і практики педагогічної сфери, особливо актуальні вони нині, у період політичних й економічних змін українського суспільства.

Від часу свого створення (1999р.) Державна науково-педагогічна бібліотека України імені В. О. Сухомлинського (далі - ДНПБ) одним із пріоритетних завдань у своїй діяльності вбачає систематичне інформаційне забезпечення наукових досліджень i практичних починань, які сприяють реформуванню й інноваційному розвитку педагогічної науки, освіти і практики в нашій державі. Позиціонуючи себе як науководослідний, науково-інформаційний, науково-методичний i координаційний центр мережі освітянських бібліотек МОН України і НАПН України, ДНПБ спрямовує зусилля на організацію системи інформаційного забезпечення освітянської галузі країни, у якій учасники даної мережі стають дієвими акторами у задоволенні інформаційних потреб фахівців освітянської галузі на сучасному етапі. Створення такої системи вимагає підгрунтя - розроблення теоретичних, науково-методичних i організаційних засад. Розроблення наукових основ формування всеукраїнського інформаційного ресурсу з психолого-педагогічних питань й освіти стало осердям низки комплексних наукових проектів, здійснюваних на базі ДНПБ упродовж 2001-2014 pp. Результати досліджень висвітлено в роботах керівників наукових проектів П. І. Рогової [2, с. 16-36; 3, с. 10-27; 5, с. 11-33], Т. В. Добко [2, с. 16-36], В. І. Лутовинової [2, 
с. 16-36; 6, с. 28-39], О. М. Яценко [4, 9-29] та інших науковців, обговорено на наукових заходах, що систематично проводилися в рамках здійснюваних досліджень.

Завдяки виконаній науково-дослідній роботі і практичному втіленню їі здобутків, можна констатувати, що в Україні створено галузеву бібліотечну мережу повноцінного інформаційного забезпечення фахових потреб освітян держави як первинними, так і вторинними документами (у традиційній і електронній формах).

Значну частину інформаційного ресурсу мережі освітянських бібліотек $\mathrm{MOH}$ i НАПН України складає фонд періодичних видань 3 переважанням часописів 3 питань педагогіки і психології. За даними останнього дослідження стану бібліотечноінформаційного забезпечення фахівців освітянської галузі (2013р.), усього фонд періодичних видань провідних українських освітянських бібліотек нараховує 2411083 примірники, або 11,54\% усього фонду; зокрема в ДНПБ фонд періодики налічує 144357 примірників, або 25,21\% внутрішнього інформаційно-бібліотечного ресурсу [9, с. 85]. За стабільної політичної й економічної ситуації в державі ці показники мають тенденцію до зростання в рамках можливостей бібліотечних установ з урахуванням фахових потреб користувачів.

Публікації в періодичних виданнях - цінне i, що важливо, оперативне джерело історичних розвідок, нових методик, інноваційних ідей і наукових розробок. Тому значущим є розкриття змісту часописів, яке можливе через створення вторинних інформаційних ресурсів, що допоможуть зорієнтуватися в інформаційних потоках. Один із таких ресурсів - електронна база бібліографічних даних статей і матеріалів періодичних видань, яка в сучасних умовах $\epsilon$ вагомою складовою довідковобібліографічного апарату бібліотеки, а эї створення - одним із пріоритетних напрямів бібліографічної діяльності бібліотечної установи. У ДНПБ така електронна база - база даних «Періодика» (далі - БД «Періодика») - існує вже майже 10 років, на 05.06.15 іiі загальний обсяг складав 192066 електронних записів (далі - Е3), зокрема аналітичних записів - 116472 . Тож є підстави для дослідження досвіду іiі створення, що буде корисним для книгозбірень освітянської галузі: допоможе уникати труднощів під час ведення подібних бібліографічно-пошукових систем, поліпшить їхню якість, ефективність використання, сприятиме втіленню новітньої стратегії формування галузевого довідково-бібліографічного ресурсу на корпоративній основі, чим, зрештою, підвищить рівень задоволення науково-інформаційних фахових потреб користувачів із питань освіти, педагогіки й психології, що матиме вплив на інтенсивність інноваційного розвитку освітянської галузі в Україні.

Аналіз останніх досліджень і публікацій. Науково-організаційні й теоретикометодичні питання електронних бібліографічних БД розглядалися в працях В. М. Горового [10], К. В. Лобузіної [11], Л. Я. Філіпової [12], Г. В. Шемаєвої [13], С. В. Зигмантович [14] та ін. Організаційно-технологічний аспект формування електронних бібліотечно-бібліографічних ресурсів досліджували Я. Л. Шрайберг [15], Д. А. Архіпов [16], О. І. Павлов [17], О. М. Волохін [18] та ін. Методико-технологічні й практичні питання створення окремих електронних БД статей i матеріалів 3 періодичних видань висвітлювали С. Бакан [19], Є. Одинець [19], О. Бодак [20; 21], А. Федорчук [20; 22], К. Лобузіна [21; 22], Н. Танатар [22]. Проте тему формування бібліографічних спеціалізованих БД з питань педагогіки, психології, освіти та практики окремо не розглядали.

У межах комплексних науково-дослідних проектів ДНПБ, про які згадувалося вище, серед інших вивчали й питання створення електронного каталогу (далі - ЕК) в ДНПБ, зокрема розкрито теоретичні, методичні й організаційні засади його формування (Н. Д. Грудініна [3, с. 218-224; 5, с. 229-239], Н. С. Зоріна [3, с. 233-240; 5, с. 207-218], С. Г. Коваленко [3, с. 225-232; 6, с. 133-142], І. Г. Лобановська [7; 8], 
О. Г. Помчалова [5, с. 197-207]); досліджено теоретичні і практичні підходи до організації окремих бібліографічних БД - складових ЕК ДНПБ - галузевої реферативної БД (І. Й. Коваленко [2, с. 129-137; 3, с. 251-255]) та зведеної БД дисертацій з питань освіти, педагогіки і психології (С. Г. Коваленко [5, с. 218-229]); висвітлено досвід корпоративної співпраці ДНПБ 3 освітянськими бібліотеками України щодо формування БД ЕК (І. Г. Лобановська [5, с. 59-67]). Окремо досліджено питання організації на корпоративних засадах обміну ЕЗ аналітичного розпису часописів для поповнення БД «Періодика» (Л. І. Самчук [3, с. 139-144]). Спеціального дослідження, присвяченого проблемам створення, функціонування, вдосконалення БД «Періодика», не проводилось.

Мета статті - дати визначення електронного бібліографічного ресурсу галузевої БД «Періодика» ДНПБ, дослідити процес їі формування, розкрити принципи побудови, окреслити модернізаційні аспекти її розвитку.

Дослідження виконано в рамках науково-дослідної роботи ДНПБ «Модернізація науково-інформаційної діяльності провідних книгозбірень мережі освітянських бібліотек МОН України та НАПН України» (керівник теми - С. М. Зозуля, канд. іст. наук, провідний науковий співробітник відділу наукової реферативної та аналітичної інформації у сфері освіти ДНПБ).

\section{2. РЕЗУЛЬТАТИ ДОСЛІДЖЕННЯ}

Започатковуючи в ДНПБ електронний бібліографічний ресурс - БД «Періодика», малося на меті:

1) інтенсифікувати процес аналітико-синтетичної обробки журналів і газет, які надходять до фонду установи, на основі новітніх комп'ютерних технологій, дотримуючись загальноприйнятих стандартів створення бібліографічних записів (далі - БЗ);

2) сформувати систему БЗ документів, у якій кожен 3 них буде забезпечений оптимальним пошуковим образом;

3) запровадити альтернативну систему, використання якої можливе на одному робочому місці з мінімальною затратою часу, на противагу віддаленим у просторі традиційним каталогам i картотекам, що розкривають фонд періодичних видань (Систематична картотека статей із періодичних видань (СКС) 3 алфавітно-предметним покажчиком до неї (АПУ), Систематична картотека статей філії № 1 (СКСф1), Абетковий каталог періодичних видань (АКП), Систематична картотека статей 3 бібліотекознавства i бібліографознавства);

4) підвищити якість обслуговування користувачів за рахунок названих вище інновацій.

Передбачалося, що БД «Періодика» формуватиметься як одиниця об'ємної структури - ЕК, але матиме свої ознаки й особливості, що й було закріплено в «Положенні про електронний каталог Державної науково-педагогічної бібліотеки України імені В. О. Сухомлинського». У ньому зазначено, що БД «Періодика» $\epsilon$ окремим елементом ЕК, який «включає Б3 періодичних видань українською, російською та іноземними мовами у цілому та аналітичні БЗ з них» [23, с. 210]. Ще одним регламентуючим організацію БД «Періодика» документом $\epsilon$ паспортхарактеристика, у якому послідовно перелічено всі основні ознаки даного ресурсу: назва, задіяна технологічна платформа, тип, тематика, галузь застосування, умови доступу тощо. Цей документ розміщено на веб-порталі ДНПБ і призначений 
насамперед для користувачів, щоб ознайомити їx iз потенціалом ресурсу i можливостями його використання [24].

На підставі окреслених завдань й організаційних засад формування БД «Періодика», ми даємо визначення: БД «Періодика» - ие представлений в електронному форматі об'єднаний масив бібліографічних даних про документальні джерела - сучасні періодичні видання $з$ питань педагогіки та психології, бібліотекознавства й бібліографії та інших суміжних наук, щзо зберігаються у фонді ДНПБ, та продукту їхнього аналітико-синтетичного опрацювання, поданого у вигляді колекиї БЗ статей $i$ матеріалів, забезпечений багатоаспектною пошуковою системою, призначений для задоволення інформачійно-бібліографічних потреб професійних користувачів галузевого спрямування та всіх зачікавлених осіб (науковопедагогічних працівників, аспірантів, учителів, студентів та ін.).

БД «Періодика», як складову ЕК ДНПБ, почали формувати з 2006 р. на основі єдиної з ЕК технологічної платформи - системи автоматизації бібліотек (САБ) ІРБІС, що $є$ досить поширеним у бібліотечному світі програмним продуктом для створення електронних ресурсів (достатньо зауважити, що на сьогодні ним послуговуються такі значущі книгозбірні, як Національна бібліотека України ім. В. І. Вернадського, Національна історична бібліотека України, Державна науково-технічна бібліотека України, а також 43 \% провідних освітянських бібліотек України [9, с. 76]). Наразі в ДНПБ впроваджена й адаптується версія САБ ІРБІС 64 [25]. БД «Періодика» створюється в автоматизованому робочому місці (АРМ) «Каталогізатор» даної системи, що призначене для бібліотечного працівника, який виконує всі функції з формування (поповнення й корегування) БД ЕК. В умовах локальної обчислювальної мережі система забезпечує функціонування довільної кількості АРМів «Каталогізатор» 3 можливістю одночасного поповнення однієї БД.

У формуванні БД «Періодика» задіяні декілька підрозділів ДНПБ. Відділ науковотехнічного забезпечення та впровадження комп'ютерних технологій забезпечує технологічну підтримку й технічний супровід ведення БД «Періодика». Biдdiл наукового комплектування фондів здійснює зведений опис періодичного видання у цілому, включаючи надання відомостей про надходження всіх його номерів і створюючи при цьому БЗ кожного окремого номера. БЗ на періодичне видання створюється українською, російською та іноземними мовами (залежно від мови часопису). Перелік полів, правила та порядок їхнього заповнення для створення БЗ періодичних видань визначено спеціальною інструкцією, розробленою у відділі на основі чинних стандартів і нормативно-інструктивних документів, які регламентують загальні правила складання Б3, використання скорочень слів у записах українською, російською та іноземною мовами [26]. На основі БЗ окремих номерів періодичних видань відбувається аналітико-синтетичне опрацювання часописів.

Аналітико-синтетичне опрацювання основного потоку газет i журналів здійснюють працівники відділу наукової інформаційно-бібліографічної діяльності та сектора науково-комплексного обслуговування (до реструктуризації ДНПБ у січні 2015 р. - філія № 1), часописи з питань бібліотекознавства й бібліографії опрацьовують у відділі наукового та прикладного бібліотекознавства, іншомовні періодичні видання - в читальній залі літератури іноземними мовами (до реструктуризації - відділ наукового формування фонду документів іноземними мовами). Відповідає за формування БД «Періодика» відділ наукової інформаційно-бібліографічної діяльності.

Для аналітико-синтетичного опрацювання журналів і газет відділом наукової інформаційно-бібліографічної діяльності розроблено окрему інструкцію «Правила заповнення полів у базі даних «Періодика» електронного каталогу ДНПБ України ім. В. О. Сухомлинського (модуль «Каталогізатор» АБІС ІРБІС)» [27], у якій викладено 
основи організації й технології роботи, загальні вимоги до заповнення полів i безпосередньо правила заповнення полів робочих аркушів введення даних. У правилах визначено набір полів, необхідних для створення аналітичних записів, розкрито зміст полів і підполів, наведено приклади їх заповнення. Згадана інструкція $\epsilon$ формою адаптації інформаційно-технологічних рішень САБ ІРБІС 64 щодо створення аналітичних записів газетно-журнальних публікацій у модулі «Каталогізатор» до умов роботи і профілю ДНПБ; іiі розроблено на основі чинних стандартів та інструктивнонормативних документів, які регламентують правила складання аналітичних Б3, використання скорочень слів у записах українською, російською та іноземними мовами, анотування й індексування документів тощо.

За інструкцією, аналітико-синтетичне опрацювання часопису вибудовується в такий ланцюжок основних операцій:

1) пошук БЗ номера періодичного видання в БД;

2) введення змісту часопису (повне або часткове) у вигляді БЗ вміщених у ньому публікацій (вводяться дані про автора/авторів, основна назва, паралельна назва, відомості до назви, відомості про відповідальність, кількісні характеристики, примітки про наявність бібліографії);

3) копіювання БЗ, що складають зміст, у БД; у результаті даної дії кожний БЗ стає самостійним елементом БД й опрацьовується в подальшому окремо один від одного;

4) бібліографічне редагування (уведення відсутніх даних у БЗ - відомостей про редакторів, укладачів, відповідальність установ та організацій, причетних до створення документа, загальних приміток тощо);

5) індексування (доповнення Б3 класифікаційними індексами за таблицями Універсальної десяткової класифікації (УДК) (Київ, 2008), предметними рубриками, ключовими словами, за потреби - географічними рубриками i персоналіями);

6) анотування (написання анотації).

Деякі із вище означених операцій, під час виконання яких у каталогізаторів можуть виникати труднощі, мають окреме методичне забезпечення. Скажімо, предметні рубрики і ключові слова формуються за проблемно-орієнтованими методиками, розробленими фахівцями відділу наукового опрацюювання документів $i$ організації каталогів на основі чинних стандартів, вивченні доробку науковців й досвіду провідних бібліотек України й зарубіжжя стосовно предметизації й індексування документів [28; 29]; анотації створюються за методикою, викладеною у методичному посібнику В. І. Лутовинової [30].

Дотримання всіх вимог щодо ведення БД «Періодика», які містяться у відповідних інструкціях і методичних посібниках, $\epsilon$ запорукою створення якісних електронних аналітичних записів, забезпечених оптимальними пошуковими можливостями.

Якість БД «Періодика» контролюється завдяки редагуванню. Під час створення аналітичних записів і в процесі експлуатації БД «Періодика» відбувається ії поточне редагування. Періодично виконується планове вибіркове редагування (за визначеними аспектами) або повне редагування (передбачає перевіряння всієї БД) відповідно до планів роботи ДНПБ і відповідального за ведення БД відділу. А це виправлення технічних помилок (описок, зайвих пробілів тощо) і внесення змін відповідно до нових методичних рішень щодо заповнення робочих аркушів введення даних.

Уся діяльність щодо побудови БД «Періодика» відбувається на основі принципів науковості, інформативності, доступності, планомірності, систематичності, оперативності, економічності. 
Застосування провідної сучасної технологічної платформи, дотримання чинних стандартів бібліографічного аналітичного опису, використання міжнародної системи класифікації документів (УДК), науково обгрунтованих методичних рішень, які враховують передовий вітчизняний і зарубіжний досвід педагогічної науки і практики, а також високий фаховий рівень наукових співробітників відділів ДНПБ, котрі забезпечують організацію, ведення, редагування БД «Періодика», - це ті чинники, завдяки яким реалізується принцип науковості у їі формуванні.

Принцип інформативності забезпечується багатоаспектним, максимально повним розкриттям вмісту фонду періодичних видань, завдяки якому виникає широкий спектр пошукових засобів, що їх забезпечує технологія САБ ІРБІС 64.

Принцип доступності реалізується, по-перше, у розташуванні персональних комп'ютерів у доступній для користувачів частині приміщення ДНПБ, де вони можуть працювати з БД «Періодика» в локальній мережі в АРМ «Читач». Робота 3 БД грунтується на клієнт-серверній платформі, що гарантує одночасне користування нею багатьох відвідувачів. По-друге, - у забезпеченні рівного і вільного доступу всім бажаючим до отримання бібліографічної інформації, яка зібрана в БД «Періодика», у мережі Інтернет на порталі ДНПБ. По-третє, - у забезпеченні багатоаспектного пошуку інформації за елементами аналітичних записів та їх поєднанням, що дає можливість користувачеві отримати найбільш повну інформацію за своїм запитом.

БД «Періодика» формується згідно з науково обгрунтованими річними планами ДНПБ, тобто розвиток БД відбувається на плановій основі, що відповідає принципу планомірності.

Принции систематичності полягає в тому, що БД «Періодика» поповнюється планомірно, регулярно (щоденно, за винятком неробочих днів тижня) та оперативно.

Відповідно до принциипу оперативності мінімізується час, витрачений на опрацювання нових надходжень і доведення його результатів до користувача, тобто забезпечується своєчасність реєстрації і введення даних про нові номери отриманої періодики та їх аналітико-синтетичного опрацювання.

Принции економічності забезпечується через цільовий розподіл обов'язків задіяних у процесі формування БД «Періодика» працівників, уникнення паралелізму в роботі.

Новий етап в організації БД «Періодика» розпочався в 2009 р., коли ДНПБ ініціювала створення системи обміну Е3 аналітичного розпису періодичних видань 3 освітянськими бібліотеками України. За період травень 2009 - вересень 2013 р. БД «Періодика» за обміном поповнилася на 10549 записів. У свою чергу, ДНПБ надіслала бібліотекам-учасницям обміну 30265 записів. Спільними зусиллями партнерів по обміну опрацьовується 125 назв журналів України і Росії 3 питань педагогіки i психології. 3 другого півріччя 2013 р. обмін Е3 здійснюється шляхом використання File Transport Protocol (FTP)-сервера, що дає змогу кожній бібліотеці-учасниці обміну самостійно запозичувати потрібні записи [31, с. 15]. Для організаційно-методичного забезпечення цього процесу розроблено спеціальну інструкцію [32]. Втілення ідеї кооперації, вираженої в об'єднанні зусиль освітянських бібліотек країни щодо аналітико-синтетичного опрацювання часописів на базі САБ ІРБІС та подальшим здійсненням обміну ЕЗ, сприяло підвищенню оперативності наповнення БД «Періодика» (як і подібних БД бібліотек-партнерів) і розвитку інтеграційних зв'язків освітянських книгозбірень у царині бібліотечно-бібліографічної діяльності.

Рух до суспільства знань активізує розвиток освіти й педагогіки, вимагає реформування, а почасти й докорінних змін у галузі, у т. ч. й науково-педагогічній сфері. Тож модернізуються й усі інструменти, які так чи інакше сприяють цьому процесу. Оскільки БД «Періодика» є одним із знарядь системного поглиблення 
інформаційного забезпечення фахівців психологічної й педагогічної наук і практики, процес іiі формування також супроводжується деякими змінами, спричиненими появою нових вимог, що висуваються до засобів і методів інформаційного забезпечення. Щодо модернізації БД «Періодика» можна висунути такі завдання:

1) забезпечення наступності в упровадженні нових версій програмнотехнологічного забезпечення БД - САБ ІРБІС за умови раціональності їх застосування. Прикладом такої раціональності може слугувати заміна спершу прийнятої версії САБ IРБІС 32 наступною САБ ІРБІС 64; оновлення технологічної платформи розширило інформативно-пошукові можливості БД;

2) забезпечення нового рівня інтеграції БД «Періодика» в структурі створюваного в ДНПБ освітнього інтегрованого галузевого інформаційного ресурсу (IГІР) відповідно до Концепції, розробленої з метою створення умов «для інтенсифікації науководослідної діяльності, навчально-виховного процесу в освітянській сфері України шляхом створення принципово нових можливостей для пошуку й використання наукової інформації, відображення в освітянському сегменті інформаційного простору інтегрованих бібліотечно-інформаційних ресурсів, надання вільного доступу до таких ресурсів незалежно від статусу й місця перебування користувачів» [33, с. 20];

3) розширення спільної діяльності з освітянськими книгозбірнями МОН і НАПН України щодо аналітико-синтетичного опрацювання фахових періодичних видань й обміну Е3 для їх подальшого введення в БД «Періодика». Узгодженості в роботі з обміну Е3 і поліпшенню їх якості сприятиме поглиблення професійної комунікації (на конференціях, семінарах, у блогах, на форумах тощо) i, насамперед, удосконалення науково-методичного супроводу учасників обміну. Останньому сприятиме й розв'язання наступних завдань;

4) розроблення стандартизованого рубрикатора для предметного опрацювання аналітичних Б3. Для забезпечення уніфікації предметних рубрик ми вже маємо науково-методичне підгрунтя [28]. Відправною точкою в цій роботі слугуватиме БД Авторитетного файлу «Предметні заголовки» ЕК, яка формується, і напрацьований масив предметних рубрик у БД «Періодика». До стандартизованих предметних рубрик доцільно вводити рубрики фактографічного спрямування, що сприятиме не лише інформаційно-бібліографічній, а й довідково-фактографічній діяльності. Наприклад, завдяки зверненню до публікацій за предметною рубрикою «Освіта - нагороди Відмінник освіти, нагрудний знак - Україна, 2014» можна отримати відомості про вказану нагороду у сфері освіти й осіб, відзначених нею у 2014 р. Причому відомостей, отриманих з БД «Періодика», почасти буде достатньо і не потребуватиме додаткового звернення до друкованих джерел;

5) перегляд «Правил заповнення полів у базі даних «Періодика» електронного каталогу ДНПБ України ім. В. О. Сухомлинського (модуль «Каталогізатор» АБІС IPБIC)» [27] 3 метою внесення можливих змін для розширення інформаційних можливостей ресурсу. Приміром, пропонуємо додати до «Правил...» пункт про обов'язковість написання ключових слів і анотацій під час опрацювання статей 3 наукових часописів не тільки українською, але й англійською і російською мовами, що надасть можливість користувачам у багатьох країнах скористатися нашим інформаційним ресурсом і сприятиме формуванню позитивного іміджу психологічної й педагогічної наук і бібліотечної справи України у світі, а також підвищить престиж ДНПБ як центральної книгозбірні освітянської галузі нашої держави. Наявність іншомовних анотацій і ключових слів є однією з обов'язкових вимог до оформлення статей, які подають автори до наукових журналів, а це набагато спрощує роботу каталогізатора; 
6) розроблення технологічних карт на процеси аналітико-синтетичного опрацювання документів для нормування робочого часу, який витрачається працівниками на їх здійснення, обгрунтованого планування і наукової організації праці у зв'язку зі змінами, внесеними до «Правил...».

Виконання поставлених завдань 3 модернізації БД «Періодика» дасть змогу значно поліпшити якість й ефективність автоматизованого опрацювання періодичних видань і рівень бібліографічного обслуговування користувачів.

\section{3. ВИСНОВКИ ТА ПЕРСПЕКТИВИ ПОДАЛЬШИХ ДОСЛІДЖЕНЬ}

На основі новітніх комп'ютерних технологій 3 використанням можливостей інтегрованого середовища бібліотечного програмного продукту САБ ІРБІС 64 в ДНПБ створений i постійно функціонує електронний бібліографічний ресурс- БД «Періодика», який розкриває зміст наявних у фонді сучасних періодичних видань. Оскільки в ДНПБ традиційно особлива увага приділяється створенню нормативнометодичних документів, значущим $є$ і нормативно-методичне забезпечення організації БД «Періодика», що значною мірою сприяє формуванню масиву ЕЗ однакової повноти і якості. Організацію БД «Періодика» регламентують такі інструктивно-нормативні і методичні документи:

- положення про ЕК;

- паспорт-характеристика БД «Періодика» ЕК;

- інструкція щодо порядку заповнення полів для створення БЗ періодичного видання в цілому в БД «Періодика» ЕК;

- інструкція щодо порядку заповнення полів для створення аналітичного запису в БД «Періодика» ЕК;

- методичні рекомендації щодо індексування документів ключовими словами;

- методичні рекомендації щодо предметизації документів 3 питань освіти, педагогіки, психології;

- інструкція щодо обміну бібліографічними записами документів для створення інтегрованого і галузевого інформаційного ресурсу на засадах кооперування.

БД «Періодика» - самодостатня одиниця ЕК, вагома складова довідковобібліографічного апарату ДНПБ, має характерні особливості, серед яких можна виокремити наступні:

1) постійно поповнюється через опрацювання нових надходжень періодичних видань фахівцями ДНПБ та Е3, отриманими внаслідок обміну 3 освітянськими бібліотеками МОН і НАПН України;

2) оперативно інформує про нові статті й матеріали завдяки своєчасному опрацюванню нових номерів отриманих часописів;

3) періодично корегується шляхом технічного й методичного редагування;

4) забезпечує швидкий пошук необхідної користувачеві інформації через оптимально сформовані пошукові образи документів;

5) загальнодоступна для користувачів в Інтернет-мережі на порталі ДНПБ і в робочі дні тижня у локальній мережі в режимі он-лайн;

6) забезпечена можливостями вдосконалення (модернізації) процесу аналітикосинтетичного опрацювання журналів i газет завдяки технологічним можливостям САБ ІРБІС 64, а, отже, і перспективами якісного покращення обслуговування користувачів.

У подальших наших планах - дослідити інформаційно-пошукові можливості бази даних «Періодика» електронного каталогу Державної науково-педагогічної бібліотеки 
України ім. В. О. Сухомлинського і форми бібліографічного обслуговування користувачів на основі ії контенту.

\section{СПИСОК ВИКОРИСТАНИХ ДЖЕРЕЛ}

1. Кремень, В. Г. Інноваційна людина і сучасна освіта / В. Г. Кремень // Вісн. Чернігів. нац. пед. унту. Серія: Педагогічні науки. - 2013. - Вип. 110. - С. 3-5.

2. Наукові праці Державної науково-педагогічної бібліотеки України імені В. О. Сухомлинського. Вип. 1. Науково-інформаційне забезпечення освітянської галузі України / АПН України, ДНПБ України ім. В. О. Сухомлинського. - Київ : Четверта хвиля, 2008. - 402 с.

3. Наукові праці Державної науково-педагогічної бібліотеки України імені В. О. Сухомлинського. Вип. 2. Всеукраїнський інформаційний ресурс з питань психолого-педагогічної науки і освіти: сучасний стан та шляхи розвитку / НАПН України, ДНПБ України ім. В. О. Сухомлинського. Київ : Пед. думка, 2010. - 320 с.

4. Наукові праці Державної науково-педагогічної бібліотеки України імені В. О. Сухомлинського. Вип. 3. Науково-методичні та організаційні засади інформаційно-аналітичного забезпечення педагогічної науки, освіти і практики України: стан та перспективи / НАПН України, ДНПБ України ім. В. О. Сухомлинського. - Київ : Нілан-ЛТД, 2012. - 373 с.

5. Наукові праці Державної науково-педагогічної бібліотеки України імені В. О. Сухомлинського. Вип. 4. Інтегрований галузевий інформаційний ресурс: стан, проблеми, перспективи створення та забезпечення доступу / НАПН України, ДНПБ України ім. В. О. Сухомлинського. - Вінниця : Нілан-ЛТД, 2014. - 597 с.

6. Науково-методичні та організаційні засади створення системи інформаційного забезпечення фахових потреб освітян України : матеріали Всеукр. наук.-практ. семінару, (м. Львів, 18-19 трав. 2006 р.) / АПН України, ДНПБ України ім. В. О. Сухомлинського. - Київ : [б. в.], 2006. - 201 с.

7. Лобановська, І. Лінгвістичне забезпечення електронного каталогу Державної науково-педагогічної бібліотеки України імені $\quad$ В. О. Сухомлинського: комплексний підхід / I. Г. Лобановська // Програмне забезпечення у сфері освіти і науки : матеріали конф., 12-13 трав. 2010 р., м. Київ / НАПН України, Ін-т інновац. технологій і змісту освіти МОН України, ДНПБ України ім. В. О. Сухомлинського [та ін.]. - Київ, 2010. - С. 63-65.

8. Лобановська, I. Науково-методичне забезпечення процесів каталогізації в бібліотеках освітянської галузі України / І. Лобановська // Історія освітянських бібліотек України : наук. зб. / АПН України, ДНПБ України ім. В. О. Сухомлинського. - Київ, 2006. - С. 114-123.

9. Провідні освітянські бібліотеки України в дзеркалі статистики : зб. аналіт. і стат. даних за 2013 p. / НАПН України, ДНПБ України ім. В. О. Сухомлинського ; [уклад.: Л. О. Біла, А. В. Копилова, Н. Б. Соколовська ; наук. ред.: Л. М. Заліток, І. І. Хемчян]. - Київ : [б. в.], 2014. - 100 с.

10. Горовий, В. М. Соціальні інформаційні бази і розвиток бібліотечного інформаційного потенціалу (1991-2006 рр.) : автореф. дис. ... д-ра іст. наук: [спец.] 07.00.08 „Книгознавство, бібліотекознавство, бібліографознавство” /Горовий Валерій Микитович ; Нац. б-ка України ім. В. І. Вернадського. - Київ : [б. в.], 2006. - 35 с.

11. Лобузіна, К. В. Знаннєві ресурси у бібліотечно-інформаційній діяльності: організація, управління, доступ : автореф. дис. ... д-ра наук із соц. комунікацій : [спец.] 27.00.03 „Книгознавство, бібліотекознавство, бібліографознавство" / Лобузіна Катерина Вілентіївна ; Нац. б-ка України ім. В. І. Вернадського. - Київ : [б. в.], 2013. - 36 с.

12. Філіпова, Л. Я. Бібліографічні системи України в інформаційно-комп'ютерному середовищі: теорія, організація, технологія : автореф. дис. ... д-ра пед. наук : [спец.] 07.00.08 „Книгознавство, бібліотекознавство, бібліографознавство” / Л. Я. Філіпова ; Харків. держ. акад. культури. Харків : [б. в.], 1999. - 34 с.

13. Шемаєва, Г. В. Електронні ресурси бібліотек України в системі наукових комунікацій: монографія / Г. В. Шемаєва ; Харків. держ. акад. культури. - Харків : ХДАК, 2008. - 288 с.

14.Зыгмантович, С. В. Формирование библиографических баз данных / С. В. Зыгмантович // Подготовка библиографической продукции библиотеками: науч.-практ. пособие / С. В. Зыгмантович. - Минск, 2009. - Гл. 4.1. - С. 160-168.

15. Шрайберг, Я. Л. Принципы построения автоматизированных библиотечно-информационных систем и сетей : автореф. дис. ... д-ра техн. наук : [специальность] 05.25.05 „Информационные системы и процессы, правовые аспекты информатики”, [специальность] 05.25 .03 „Библиотековедение, библиографоведение и книговедение” / Я. Л. Шрайберг ; Гос. публ. науч.техн. б-ка России. - Москва : [б. и.], 1999. - 40 с. 
16. Архипов, Д. А. Библиотечно-функциональный анализ отечественных автоматизированных библиотечно-информационных систем : автореф. дис. ... канд. пед. наук : [специальность] 05.25.03 „Библиотековедение, библиографоведение и книговедение”/ Дмитрий Анатольевич Архипов ; Федер. гос. образоват. учреждение высш. и проф. образования «Московский государственный университет культуры и искусств». - Москва : [б. и.], 2008. -16 с.

17. Павлов, А. И. Современная техническая база крупной библиотеки / А. И. Павлов // Библиосфера. 2014. - № 3. - С. 58-68.

18. Волохін, О. ІРБІС: система автоматизації бібліотек / Олег Волохін // Бібл. форум України. 2003. - № 2. - C. 8-10.

19. Бакан, С. Політематична база даних статей з періодичних видань Національної парламентської бібліотеки України / С. Бакан, С. Одинець // Бібл. планета. - 2004. - № 2. - С. 12-14.

20.Бодак, О. Електронний інформаційний ресурс «Національна бібліотека України імені В. І. Вернадського у дзеркалі газетної періодики» / Ольга Бодак, Артур Федорчук // Бібл. вісн. 2011. - № 5. - С. 33-37.

21. Бодак, О. Інформаційні ресурси Національної бібліотеки України імені В. І. Вернадського як джерело формування іміджу держави / Ольга Бодак, Катерина Лобузіна // Наук. пр. Нац. б-ки України ім. В. І. Вернадського / Нац. б-ка України ім. В. І. Вернадського. - Київ, 2013. - Вип. 35. C. 49-58.

22. Федорчук, А. Створення інформаційних ресурсів на основі моніторингу змісту публікацій ЗМІ / Артур Федорчук, Катерина Лобузіна, Ніла Танатар // Бібл. вісн. - 2011. - № 2. - С. 21-25.

23. Положення про електронний каталог Державної науково-педагогічної бібліотеки України імені В. О. Сухомлинського : затв. вченою радою ДНПБ України ім. В. О. Сухомлинського, протокол № 7 від 20 черв. 2011 р. // Організаційно-управлінські, нормативно-інструктивні і методичні документи для освітянських бібліотек Міністерства освіти і науки України та Національної академії педагогічних наук України (2011-2013рр.) : [збірник] / НАПН України, ДНПБ України ім. В. О. Сухомлинського. - Київ, 2013. - С. 208-213.

24. Паспорт-характеристика бази даних «Періодика» електронного каталогу Державної науковопедагогічної бібліотеки України імені В. О. Сухомлинського [Електронний ресурс] : затв. вченою радою ДНПБ України ім. В. О. Сухомлинського, протокол № 6 від 25 черв. 2009 р. // Державна науково-педагогічна бібліотека України імені В. О. Сухомлинського НАПН України: [офіц. сайт]. - Текст. http://www.dnpb.gov.ua/electronic_resources/elec_res/?PHPSESSID=43fded0ce2503659ec3a1e71d933d e6f (дата звернення: 28.04.15). - Назва з екрана.

25. Система автоматизации библиотек ИРБИС 64 : общее описание системы. - Москва: ГПНТБ России, 2004. - $411 \mathrm{c.}$

26. Заповнення полів у базі даних «Періодика» електронного каталогу ДНПБ України ім. В. О. Сухомлинського : інструкція : затв. вченою радою ДНПБ України ім. В. О. Сухомлинського, протокол № 10 від 17 листоп. 2011 р. // Організаційно-управлінські, нормативно-інструктивні і методичні документи для освітянських бібліотек Міністерства освіти і науки України та Національної академії педагогічних наук України (2011-2013 рр.) : [збірник] / НАПН України, ДНПБ України ім. В. О. Сухомлинського. - Київ, 2013. - С. 310-321.

27. Правила заповнення полів у базі даних «Періодика» електронного каталогу ДНПБ України ім. В. О. Сухомлинського (модуль «Каталогізатор» АБІС ІРБІС) : інструкція : затв. вченою радою ДНПБ України ім. В. О. Сухомлинського, протокол № 11 від 26 листоп. 2010 р. // Організаційноуправлінські, нормативно-інструктивні і методичні документи для освітянських бібліотек Міністерства освіти і науки України та Національної академії педагогічних наук України (20112013 рр.) : [збірник] / НАПН України, ДНПБ України ім. В. О. Сухомлинського. - Київ, 2013. C. 322-354.

28. Предметизація документів з питань освіти, педагогіки, психології : практ. посіб. / уклад.: І. Г. Лобановська, Н. С. Зоріна ; НАПН України, ДНПБ України ім. В. О. Сухомлинського, Від. наук. опрацювання й каталогізації документів // Наук. пр. Держ. наук.-пед. б-ки України ім. В. О. Сухомлинського / НАПН України, ДНПБ України ім. В. О. Сухомлинського. - Вінниця, 2014. - Вип. 4 : Інтегрований галузевий інформаційний ресурс: стан, проблеми, перспективи створення та забезпечення доступу. - С. 401-531.

29. Індексування документів ключовими словами : метод. рек. / [уклад. І. Г. Лобановська] ; НАПН України, ДНПБ України ім. В. О. Сухомлинського. - Київ : Нілан-ЛТД, 2011. - 53 с. - (Серія «На допомогу професійній самоосвіті працівників освітянських бібліотек» ; вип. 9).

30. Анотування як процес аналітико-синтетичної переробки інформації : метод. посіб. / авт.-уклад. В. І. Лутовинова; МОН України, ХДПУ ім. Г. С. Сковороди, АПН України, ДНПБ України ім. В. О. Сухомлинського. - Харків, 2003. - 44 с. 
31. Самчук, Л. Державна науково-педагогічна бібліотека України імені В. О. Сухомлинського як ініціатор корпоративної взаємодії освітянських бібліотек країни / Лариса Самчук // Бібл. форум України. - 2014. - № 2. - С. 13-15.

32. Обмін бібліографічними записами документів для створення інтегрованого галузевого інформаційного ресурсу на засадах кооперування : інструкція / НАПН України, ДНПБ України ім. В. О. Сухомлинського, Від. наук.-техн. забезп. та впровадж. комп'ютер. технологій. - Київ, 2012. $-6 \mathrm{c}$

33. Концепція створення інтегрованого галузевого інформаційного ресурсу в Державній науковопедагогічній бібліотеці України імені В. О. Сухомлинського / [Рогова П. І., Артемов Ю. І., Вараксіна Н. В., Лобановська І. Г. ; наук. ред. Рогова П. І.] ; НАПН України, ДНПБ України ім. В. О. Сухомлинського. - Вінниця : Нілан-ЛТД, 2013. - 20 с.

Матеріал надійшов до редакиї 10.06.2015 p.

\title{
ФОРМИРОВАНИЕ БАЗЫ ДАННЫХ «ПЕРИОДИКА» ЭЛЕКТРОННОГО КАТАЛОГА ГОСУДАРСТВЕННОЙ НАУЧНО-ПЕДАГОГИЧЕСКОЙ БИБЛИОТЕКИ УКРАИНЫ ИМЕНИ В. А. СУХОМЛИНСКОГО: ДОСТИЖЕНИЯ И ВОЗМОЖНОСТИ МОДЕРНИЗАЦИИ
}

\author{
Демида Евгения Фёдоровна \\ научный сотрудник отдела научной информационно-библиографической деятельности \\ Государственная научно-педагогическая библиотека Украины имени В. А. Сухомлинского, \\ г. Киев, Украина \\ EvgeshaDem@i.ua
}

\begin{abstract}
Аннотация. В статье представлен информационный библиографический ресурс- база данных «Периодика» электронного каталога Государственной научно-педагогической библиотеки Украины имени В.А. Сухомлинского, раскрывающий содержание фонда современных периодических изданий библиотеки. Освещены организационные аспекты формирования данного ресурса и обозначен ряд задач по его модернизации, решение которых могут обеспечить возможности технологической платформы базы данных система автоматизации библиотек (САБ) ИРБИС 64. Выполнение задач позволит значительно улучшить качество и эффективность автоматизированной аналитикосинтетической обработки периодических изданий и уровень библиографического обслуживания пользователей.
\end{abstract}

Ключевые слова: Государственная научно-педагогическая библиотека Украины имени В. А. Сухомлинского; периодические издания; библиографическая база данных; электронный каталог; САБ ИРБИС 64; модернизация.

\section{FORMATION OF E-CATALOGUE “PERIODICALS” DATABASE OF V. O. SUKHOMLYNSKYI STATE SCIENTIFIC AND PEDAGOGICAL LIBRARY OF UKRAINE: ACHIEVEMENTS AND POTENTIAL OF MODERNIZATION}

\author{
Ievheniia F. Demyda \\ Researcher of the Department of Scientific Information and Bibliographic Activity \\ V. O. Sukhomlynskyi State Scientific and Pedagogical Library of Ukraine, Kyiv, Ukraine \\ EvgeshaDem@i.ua
}

\begin{abstract}
The article presents the information and bibliographic resource - e-catalogue "Periodicals" database of V. O. Sukhomlynskyi State Scientific and Pedagogical Library of Ukraine, which shows the content of the fund of the library contemporary periodicals. The author describes organizational aspects of this resource formation and the tasks concerning its modernization, the solution of which can provide for potential of the database technological platform - IRBIS 64 Library Automation System (LAS). Carrying out tasks will make it possible
\end{abstract}


to improve the quality and efficiency of the automatized analytical-synthetic processing of periodicals and the level of bibliographic service of readers considerably.

Keywords: V. O. Sukhomlynskyi State Scientific and Pedagogical Library of Ukraine; periodicals; bibliographic database; e-catalogue; IRBIS 64 LAS; modernization.

\section{REFERENCES (TRANSLATED AND TRANSLITERATED)}

1. Kremen V. H. Innovative person and modern education / V. H. Kremen // Visn. Chernihiv. nats. ped. untu. Seriia: Pedahohichni nauky. - 2013. - Vyp. 110. - S. 3-5 (in Ukrainian).

2. Scientific works of the V. O. Sukhomlynskyi State Scientific and Pedagogical Library of Ukraine. Issue 1. Scientific and information support of educational sphere of Ukraine / APN Ukrainy, DNPB Ukrainy im. V. O. Sukhomlynskoho. - Kyiv : Chetverta khvylia, 2008. - 402 s. (in Ukrainian).

3. Scientific works of the V. O. Sukhomlynskyi State Scientific and Pedagogical Library of Ukraine. Issue 2. Ukrainian information resource for psychological and pedagogical science and education: current situation and ways of development / NAPN Ukrainy, DNPB Ukrainy im. V. O. Sukhomlynskoho. Kyiv : Pedahohichna dumka, 2010. - 320 s. (in Ukrainian).

4. Scientific works of the V. O. Sukhomlynskyi State Scientific and Pedagogical Library of Ukraine. Issue 3. Scientifically methodical and organizational principles of information and analytical support of teaching science, education and practice in Ukraine: state and prospects / NAPN Ukrainy, DNPB Ukrainy im. V. O. Sukhomlynskoho. - Kyiv : Nilan-LTD, 2012. - 373 s. (in Ukrainian).

5. Scientific works of the V. O. Sukhomlynskyi State Scientific and Pedagogical Library of Ukraine. Issue 4. Integrated sectoral information resource: state, problems and prospects of creation and access / NAPN Ukrainy, DNPB Ukrainy im. V. O. Sukhomlynskoho. - Vinnytsia : Nilan-LTD, 2014. - 597 s. (in Ukrainian).

6. Scientific-methodical and organizational principles of creation of information system needs of professional educators Ukraine: materials Ukrainian scientific-practical seminar (Lviv, 18-19 May, 2006) / APN Ukrainy, DNPB Ukrainy im. V. O. Sukhomlynskoho. - Kyiv : [b. v.], 2006. - 201 s. (in Ukrainian).

7. Lobanovska I. Linguistic providing electronic catalog of the V. O. Sukhomlynskyi State Scientific and Pedagogical Library of Ukraine: an integrated approach / I. Lobanovska // Software in Education and Science : materials conference, 12-13 May, 2010, Kyiv / NAPN Ukrainy, In-t innovats. tekhnolohii i zmistu osvity MON Ukrainy, DNPB Ukrainy im. V. O. Sukhomlynskoho [ta in.]. - Kyiv, 2010. - S. 6365 (in Ukrainian).

8. Lobanovska I. Scientific-methodical support cataloging process in libraries of educational sphere Ukraine / I. Lobanovska // Istoriia osvitianskykh bibliotek Ukrainy : nauk. zb. / APN Ukrainy, DNPB Ukrainy im. V. O. Sukhomlynskoho. - Kyiv, 2006. - S. 114-123 (in Ukrainian).

9. Leading educational libraries of Ukraine in the mirror of statistic : zb. analit. i stat. danykh za $2013 \mathrm{r}$. / NAPN Ukrainy, DNPB Ukrainy im. V. O. Sukhomlynskoho ; [uklad.: L. O. Bila, A. V. Kopylova, N. B. Sokolovska ; nauk. red.: L. M. Zalitok, I. I. Khemchian]. - Kyiv : [b. v.], 2014. - 100 s. (in Ukrainian).

10. Horovyi V. M. Social information bases and development of library information potential (1991-2006 years) : avtoref. dys. ... d-ra ist. nauk: [spets.] 07.00.08 / Horovyi Valerii Mykytovych; Nats. b-ka Ukrainy im. V. I. Vernadskoho. - Kyiv : [b. v.], 2006. - 35 s. (in Ukrainian).

11. Lobuzina K. V. Knowledge resources in the library and information activity: organization, management, access : avtoref. dys. ... d-ra nauk iz sots. komunikatsii : [spets.] 27.00.03 /Lobuzina Kateryna Vilentiivna ; Nats. b-ka Ukrainy im. V. I. Vernadskoho. - Kyiv : [b. v.], 2013. - 36 s. (in Ukrainian).

12. Filipova L. Ia. Bibliographic systems of Ukraine in information and computer environment: theory, organization, technology : avtoref. dys. ... d-ra ped. nauk: [spets.] 07.00 .08 / L. Ia. Filipova ; Kharkiv. derzh. akad. kultury. - Kharkiv : [b. v.], 1999. - 34 s. (in Ukrainian).

13. Shemaieva H. V. Electronic resources of libraries of Ukraine in the system of scientific communications : monohrafiia / H. V. Shemaieva ; Kharkiv. derzh. akad. kultury. - Kharkiv : KhDAK, 2008. - 288 s. (in Ukrainian).

14. Zygmantovich S. V. Formation of bibliographic databases / S. V. Zygmantovich // Podgotovka bibliograficheskoj produkcii bibliotekami : nauch.-prakt. posobie / S. V. Zygmantovich. - Minsk, 2009. G1. 4.1. - S. 160-168 (in Russian).

15. Shrajberg Ja. L. Principles of construction of automated library-information systems and networks : avtoref. dis. ... d-ra tehn. nauk : [special'nost'] 05.25.05, 05.25.03 / Ja. L. Shrajberg ; Gos. publ. nauch.tehn. b-ka Rossii. - Moskva : [b. i.], 1999. - 40 s. (in Russian). 
16. Arhipov D. A. Library-functional analysis of domestic automated library information systems : avtoref. dis. ... kand. ped. nauk : [special'nost'] 05.25.03 / Dmitrij Anatol'evich Arhipov; Feder. gos. obrazovat. uchrezhdenie vyssh. i prof. obrazovanija «Moskovskij gosudarstvennyj universitet kul'tury i iskusstv». Moskva : [b. i.], 2008. - 16 s. (in Russian).

17. Pavlov A. I. Modern technical base of large library / A. I. Pavlov // Bibliosfera. - 2014. - № 3. - S. 58-68 (in Russian).

18. Volokhin O. IRBIS: system of the automation of libraries / Oleh Volokhin // Bibl. forum Ukrainy. 2003. - № 2. - S. 8-10 (in Ukrainian).

19. Bakan S. Polythematic database of articles from periodicals in National Parliamentary Library of Ukraine / S. Bakan, Ie. Odynets // Bibl. planeta. - 2004. - № 2. - S. 12-14 (in Ukrainian).

20. Bodak O. Electronic information resource «Vernadsky National Library of Ukraine in the mirror of newspaper periodicals» / Olha Bodak, Artur Fedorchuk // Bibl. visn. - 2011. - № 5. - S. $33-37$ (in Ukrainian).

21. Bodak O. Information resources Vernadsky National Library of Ukraine as the source of the image of the state / Olha Bodak, Kateryna Lobuzina // Nauk. pr. Nats. b-ky Ukrainy im. V. I. Vernadskoho / Nats. b-ka Ukrainy im. V. I. Vernadskoho. - Kyiv, 2013. - Vyp. 35. - S. 49-58 (in Ukrainian).

22. Fedorchuk A. Creation of information resources through monitoring media content of publications / Artur Fedorchuk, Kateryna Lobuzina, Nila Tanatar // Bibl. visn. - 2011. - № 2. - S. 21-25 (in Ukrainian).

23. Regulation on the electronic catalog of the V. O. Sukhomlynskyi State Scientific and Pedagogical Library of Ukraine: zatv. vchenoiu radoiu DNPB Ukrainy im. V. O. Sukhomlynskoho, protokol № 7 vid 20 cherv. 2011 r. // Orhanizatsiino-upravlinski, normatyvno-instruktyvni i metodychni dokumenty dlia osvitianskykh bibliotek Ministerstva osvity i nauky Ukrainy ta Natsionalnoi akademii pedahohichnykh nauk Ukrainy (2011-2013 rr.): [zbirnyk] / NAPN Ukrainy, DNPB Ukrainy im. V. O. Sukhomlynskoho. - Kyiv, 2013. - S. 208-213 (in Ukrainian).

24. Passport-description of the database «Periodicals» of electronic catalog of the V. O. Suchomlynskyi State Scientific and Pedagogical Library of Ukraine [online]: zatv. vchenoiu radoiu DNPB Ukrainy im. V. O. Sukhomlynskoho, protokol № 6 vid 25 cherv. 2009 r. // Derzhavna naukovo-pedahohichna biblioteka Ukrainy imeni V. O. Sukhomlynskoho NAPN Ukrainy : [ofits. sait]. - Tekst. dani. - Kyiv, 2009. - Available from: http://www.dnpb.gov.ua/electronic_resources/elec_res/?PHPSESSID=43fded0ce2503659ec3a1e71d933d e6f (in Ukrainian).

25. IRBIS 64 system of the automation of libraries : obshhee opisanie sistemy. - Moskva : GPNTB Rossii, 2004. - 411 s. (in Russian).

26. Filling in the fields in the database «Periodicals» of electronic catalog of the V. O. Suchomlynskyi State Scientific and Pedagogical Library of Ukraine: instruktsiia : zatv. vchenoiu radoiu DNPB Ukrainy im. V. O. Sukhomlynskoho, protokol № 10 vid 17 lystop. 2011 r. // Orhanizatsiino-upravlinski, normatyvno-instruktyvni i metodychni dokumenty dlia osvitianskykh bibliotek Ministerstva osvity i nauky Ukrainy ta Natsionalnoi akademii pedahohichnykh nauk Ukrainy (2011-2013 rr.): [zbirnyk] / NAPN Ukrainy, DNPB Ukrainy im. V. O. Sukhomlynskoho. - Kyiv, 2013. - S. 310-321 (in Ukrainian).

27. Rules of fill the fields in the database «Periodicals» of electronic catalog of the Suchomlynsky State Scientific Pedagogical Library of Ukraine (module «Cataloguer» IRBIS ALIS) : instruktsiia: zatv. vchenoiu radoiu DNPB Ukrainy im. V. O. Sukhomlynskoho, protokol № 11 vid 26 lystop. $2010 \mathrm{r}$. // Orhanizatsiino-upravlinski, normatyvno-instruktyvni i metodychni dokumenty dlia osvitianskykh bibliotek Ministerstva osvity i nauky Ukrainy ta Natsionalnoi akademii pedahohichnykh nauk Ukrainy (2011-2013 rr.) : [zbirnyk] / NAPN Ukrainy, DNPB Ukrainy im. V. O. Sukhomlynskoho. - Kyiv, 2013. - S. 322-354 (in Ukrainian).

28. Subject headings of documents on education, pedagogy, psychology: prakt. posib. / uklad.: I. H. Lobanovska, N. Ie. Zorina ; NAPN Ukrainy, DNPB Ukrainy im. V. O. Sukhomlynskoho, Vid. nauk. opratsiuvannia i katalohizatsii dokumentiv // Nauk. pr. Derzh. nauk.-ped. b-ky Ukrainy im. V. O. Sukhomlynskoho / NAPN Ukrainy, DNPB Ukrainy im. V. O. Sukhomlynskoho. - Vinnytsia, 2014. - Vyp. 4 : Intehrovanyi haluzevyi informatsiinyi resurs: stan, problemy, perspektyvy stvorennia ta zabezpechennia dostupu. - S. 401-531 (in Ukrainian).

29. Indexing of the documents keywords : metod. rek. / [uklad. I. H. Lobanovska] ; NAPN Ukrainy, DNPB Ukrainy im. V. O. Sukhomlynskoho. - Kyiv: Nilan-LTD, 2011. - 53 s. - (Seriia «Na dopomohu profesiinii samoosviti pratsivnykiv osvitianskykh bibliotek»; vyp. 9) (in Ukrainian).

30. Annotate as process of analytical and synthetic processing of information: metod. posib. / avt.-uklad. V. I. Lutovynova; MON Ukrainy, KhDPU im. H. S. Skovorody, APN Ukrainy, DNPB Ukrainy im. V. O. Sukhomlynskoho. - Kharkiv, 2003. - 44 s. (in Ukrainian). 
31. Samchuk L. V. O. Sukhomlynskyi State Scientific and Pedagogical Library of Ukraine as the initiator of corporate interaction of educational libraries in the country / Larysa Samchuk // Bibl. forum Ukrainy. 2014. - № 2. - S. 13-15 (in Ukrainian).

32. Exchange of bibliographic records documents to create integrated information resource industry on the basis of co-operation : instruktsiia / NAPN Ukrainy, DNPB Ukrainy im. V. O. Sukhomlynskoho, Vid. nauk.-tekhn. zabezp. ta vprovadzh. komp'iuter. tekhnolohii. - Kyiv, 2012. - 6 s. (in Ukrainian).

33. The concept of integrated sectoral information resource in the V. O. Sukhomlynskyi State Scientific and Pedagogical Library of Ukraine / [Rohova P. I., Artemov Iu. I., Varaksina N. V., Lobanovska I. H. ; nauk. red. Rohova P. I.] ; NAPN Ukrainy, DNPB Ukrainy im. V. O. Sukhomlynskoho. - Vinnytsia: NilanLTD, 2013. - 20 s. (in Ukrainian).

\section{(cc) $\mathrm{EY}-\mathrm{NC}-\mathrm{SA}$}

This work is licensed under Creative Commons Attribution-NonCommercial-ShareAlike 4.0 International License. 